\title{
CHILDREN'S MOTOR SKILLS VS. VIRTUAL REALITY
}

\author{
Irina BĂIȚEL ${ }^{*}$, Luminița PĂTRU ${ }^{2}$ \\ 1 "Dante Alighieri" Theoretical High School, Bucharest, Romania \\ ${ }^{2}$ National University of Physical Education and Sport, Faculty of Physical Education and Sport, Bucharest, Romania \\ *Corresponding author: irina_baitel@yahoo.com
}

DOI: $10.35189 /$ iphm.icpesk.2019.3

\begin{abstract}
It is already known that, beyond the huge benefits of technology in simplifying certain aspects of life, its excessive use affects children's brains (and not only), causing attention problems, addiction, tiredness, irritability, sometimes even depression and bipolar disorder. Socially, the time spent in virtual reality or using the new technologies is subdued from the time people/children have the opportunity to socialise, interact or play in the real world in the company of other children, this having negative influences on the development of their communication abilities and emotional intelligence. There are, however, experts who claim that technology has more advantages than disadvantages on children, one of which being that, by using touch screens, children learn much faster. We believe that it is vital to find a balance in the use of technology and we want to see to what extent its influences are found in the motor performance of the children being monitored. We have identified how much time they spend per day using their smartphones/ game consoles/laptops/ personal computers. On the basis of a questionnaire designed by us and a few tests for the evaluation of motor skills applied to children in grades 4 of the "Dante Alighieri" Theoretical High School, we present in this paper a correlation between the time allocated for practicing sports training, movement games, dance and the time spent playing virtual reality games, watching movies, Internet surfing and socialising in the virtual environment, and children's motor performance.
\end{abstract}

Keywords: technology, children, motor skills.

\section{Introduction}

The term "technology" refers to methods, systems and devices that have been obtained through the use of scientific knowledge for practical purposes (“Technology”, n.d.).

Technology appears in almost every aspect of life, often making it easier, better and, why not, different. Technology has changed our lives and, for a large part of the world's population, the good course of life is closely related to technology. It serves most of the important areas of modern society, such as education, communications, business, health and scientific progress.

Technologies have been emerging and affecting our lives in ways that indicate we are at the beginning of a Fourth Industrial Revolution, a new era that is building and extending the impact of digitisation in new and unanticipated ways (Montresor, 2016).

Specialists admit that technology can influence our lives in both good and bad ways; the new technologies will always change our lives and lead them to another level, it just remains to be seen how much better the new level will be, as in sports training electronic devices like iPad and laptop are used to develop new ways to improve skills (Szabo, Neagu, Teodorescu, Pomohaci, \& Sopa, 2019a). Certainly, on a material level, the stage jump is considerable. With regard to health, we have, on the one hand, huge benefits at the level of medical equipment, research and production of medicines, therapy and life support. On the other hand, the addiction to the technology embedded in today's gadgets that are now available to almost anyone whose age is incredibly small (3-4 years old or less!) has negative effects on the users' physical and mental health.

\section{Generation transition and consequences on children}

Following the $\mathrm{Y}$ generation (of digital natives, who benefited from information technology early, having permanent access to the Internet), the $\mathrm{Z}$ (aping) generation seems to live in virtual communities rather than real ones, and it seems impossible to imagine the world and the life without connecting to the Internet the different gadgets that they naturally hold. This is where the disputes, conflicts and crisis begin, which will lead to a new "revolution" in the way of thinking, perception and use of the resources offered by computer technology.

The well-known sociologist and futurist McCrindle (2014) presents the situation as follows: today's grandparents are part of the Baby Boomers generation (born between 1946 and 1964) or the X generation (19651969). Today's young or potential parents are members of the Y generation (1980-1994). Today's children and teenagers belong to the Z Generation (1995-2009). Children born after 2010 form a new generation, Alpha, that is perhaps the most versatile of all due to its growth simultaneously with massive changes in technology. (Table 1) 
International Proceedings of Human Motricity/ ICPESK 2019

Supplementary Issue of Discobolul - Physical Education, Sport and Kinetotherapy Journal, 2019

Table 1. Generation as defined by McCrindle (2014)

\begin{tabular}{lccccc}
\hline & Builders & Baby Boomers & Generation X & Generation Y & Generation Z \\
& 1925-1945 & $1946-1964$ & $1965-1979$ & $1980-1994$ & $1995-2010$ \\
& Aged 70-80 & Aged 50-60 & Aged 30-40 & Aged 21-early 30 & Aged kids-teens \\
\hline Iconic & Radio (wireless) & TV (56) & VCR (76) & Internet, email, & MacBook, iPad, \\
technology & Motor vehicle & Audio cassette (62) & Walkman & SMS, DVD (95) & Google, \\
& Aircraft & Transistor Radio & $(79)$ & Playstation, Xbox, & Facebook, \\
& & $(55)$ & IBM PC (81) & iPod & Twitter, Wii, \\
& & & & PS3, Android \\
\hline
\end{tabular}

\section{Technology and its impact on children}

Technology has not only entered into our lives with good things. And this becomes very obvious in growing up kids having "these wonderful gadgets" at hand. Watching TV or other screens positions the child in a passive state, being just a witness who cannot interact and influence the events viewed. According to Dr Roxana Clinciu, a clinical psychologist at the Association for Therapeutic Intervention in Autism (CSID, 2017), about 80\% of the parents who presented with their children for a psychological assessment were worried about their late development and admitted that their children had access to a TV/ tablet/ phone at least 2 hours a day, sometimes even 5-6 hours. Specialists state that, when a child watches TV, there are special changes in their brain functions: the brain waves change, inducing the state of passivity, relaxation and light sleep; the communication between the two hemispheres is almost interrupted; the left-hemisphere function is inhibited, while the activity of the right hemisphere increases. The child's social behaviour changes, socialisation moving into the online environment. School group cohesion is very important in enhancing group performance, and, if there are positive relations of sympathy, friendship and cooperation, the work is more effective (Sopa, 2014a). Although access to almost any type of information is free, personal feelings and experiences are reduced proportionally to the time spent in front of a gadget. Co-innovation is facilitated in the virtual environment, but it only changes ideas, not emotions, for which an approach would be needed. Sports activities are an important framework for socialisation and social integration of children, because spending time together can help improve their social abilities and school group cohesion. (Sopa, 2014b)

According to Noel (2018), a communication management specialist and member of the ESPERE International Institute in Paris, the inability of many children to adapt to new environments, new situations or other children is more and more present. However, there is nothing wrong with the generation itself. The problem often lies in the way parents act. In order to connect to the real world, a child needs responsiveness, interaction and appropriate responses from the very first days of life to be able to respond in the same way. In other words, the attention we pay (and thus the time offered) to children will act as a catalyst between them and the surrounding world.

That is why it is totally wrong to give the child a gadget (smartphone, tablet) to connect with the today's world, because the likelihood of social isolation often increases Internet addiction, whose shortcomings are neglected: low self-esteem, lack of attention, poor school results, frustration and aggression. At a closer look, it can be seen that loneliness is a cause, not a consequence of Internet addiction, so all depends on parents and the environment they create for their children.

On the other hand, although motor involvement is extremely low in online activities (two fingers are used in principle), cerebral stimulation is quite large (the brain areas) but kinaesthetically is extremely low. Specialists are already talking about dementia in children due to the non-activation of certain brain areas involved in real representations. Furthermore, spine specialists already use the term "text neck" to describe the disorders resulting from the long-term use of socialising gadgets. This increases the risk for a poor attitude to turn into a chronic condition of the cervical and thoracic spine. Dry eye syndrome at first and then even early vision impairment are other drawbacks that come hand in hand with the use of gadgets. Last but not least, the time spent using them is subtracted from the time spent doing sports, motor activities and truly recreational activities.

Some scientific studies (Szabo, Neagu, Teodorescu, Pomohaci, \& Sopa, 2019b) regarding the influence of electronic devices on children's bodies discovered a statistically significant negative influence of these devices on the spine (lordosis, kyphosis and scoliosis). In the same article, the above authors concluded that swimming prophylaxis could prevent or slow down the occurrence of spine, knee and flat feet deficiencies in children. 


\section{Hypothesis of the research}

The irrational use of information technology, e.g. social media and video games, has a negative impact on child development, including motor performance, i.e. most of the children playing longer on their devices or surfing the Internet have poorer results in motor activity tests than children spending less time on this kind of devices. This assertion is based on the premise that the time spent on these activities is practically subtracted from the time children could allocate to motor activities (performance sports or simple movement games).

\section{Material and Methods}

This study highlights how the technology embedded into gadgets to which 9-11 year olds have access (in terms of time spent playing video games, surfing the Internet or using social networks) influences children's motor performance. First, we applied a questionnaire to 116 children, fourth grade students from the "Dante Alighieri" Theoretical High School in Bucharest, to find out how much time they spend on video games and socialising or surfing the Internet, as well as other information such as:

- how children spend their free time (reading, playing outside with friends, watching TV, playing video games, socialising on the Internet);

- favourite games (sports games, other games with children in the real world, PC, IPad, smartphone, game console, video games);

- daily time allocated to video games and the Internet;

- preference to play with children in the real world or in the virtual world;

- how children perceive their lives without contact with computer technology.

We also tested kids in terms of motor activity using the following tests:

- $30 \mathrm{~m}$ Running speed test

- 3 x 10 m Shuttle

- Long jump

- 400 m Run

- Flexibility (the test was carried out according to the protocol described for the Biomotor potential) (Institutul Național de Cercetare pentru Sport, 2016)

- On-line response time experiments (Neuroscience for kids, 2017) - this is a penalty test if the Stop button is pressed before the on-screen indication appears. After five attempts, the response time for each of them is added up (with penalties, where appropriate), and then the average value calculated for each subject is displayed.

\section{Results}

\section{Data interpretation}

After interpreting the subjects' responses, we have obtained the following information: 55\% of children practice a leisure sport at least two times per week, and $45 \%$ do not practice motor activities. $34 \%$ of them spend time playing on the phone/ tablet/ console/ PC whenever they want, while $21 \%$ spend $2-3$ hours daily, and $45 \%$, less than 1 hour a day. 


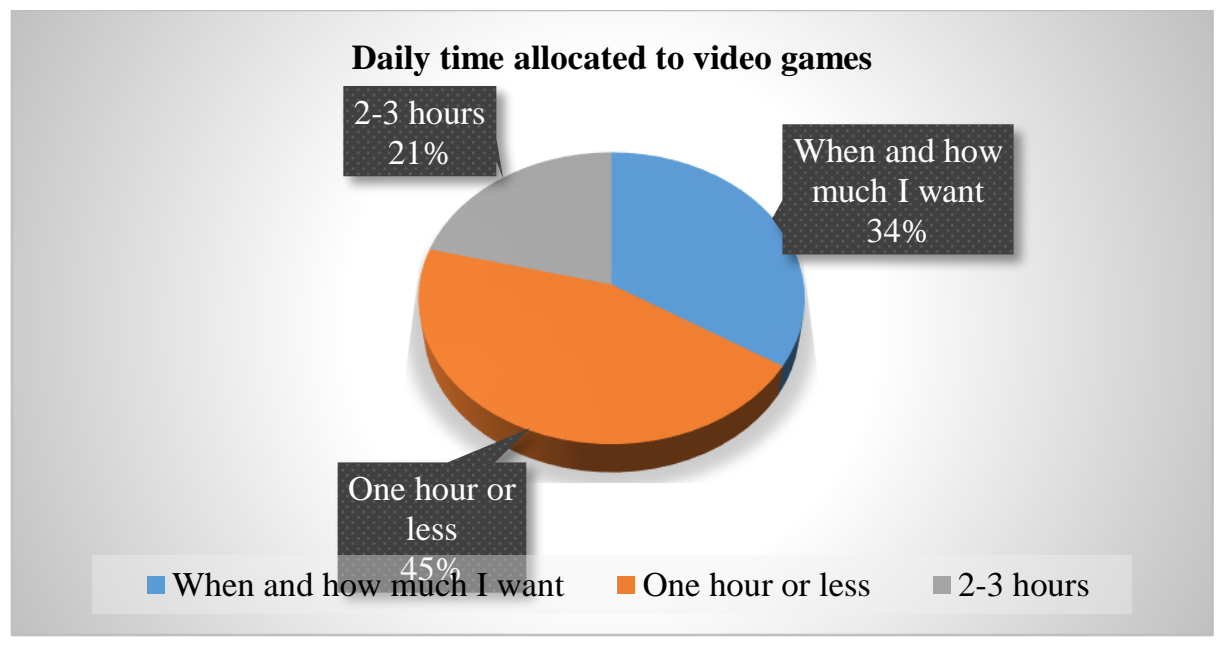

Figure 1. Children's habits: Daily time allocated to video games

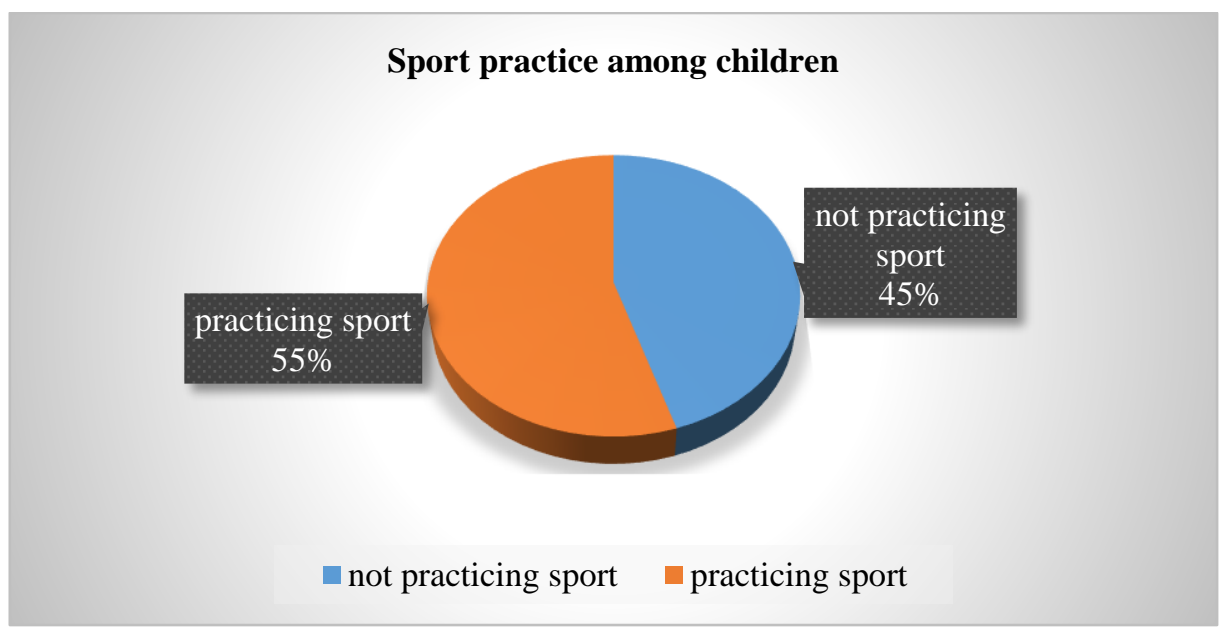

Figure 2. Children's habits: Sport practice among children

Bedtime is between $9-10 \mathrm{pm}$ for $58 \%$ of them and exceeds $10 \mathrm{pm}$ for $26 \%$, even if classes begin at 8 am. $34 \%$ of children wake up tired in the morning. $61 \%$ of them prefer to play with other children in the real world, $26 \%$ prefer to play a video game with a friend and talk about it, and $13 \%$ prefer to play video games alone. Regarding how children think about their lives without gadgets, the responses are slightly more nuanced: $11 \%$ think it would be the same, $49 \%$ think their lives would be better (of them, $15 \%$ think it would better to have more children to play with), $7 \%$ think their health would be less affected in the absence of gadgets, $7 \%$ think it would be better but it would be hard to tell in what), $13 \%$ believe it would be difficult but they would manage, $14 \%$ think it would be boring, and $13 \%$ think it would be terrible.

Table 2. Play time among children practicing sport and not practicing sport

\begin{tabular}{lcc}
\hline \multicolumn{1}{c}{ Play time } & less than 1 hour daily & more than 2 hours daily \\
\hline Children practicing sport & 40 & 22 \\
Children not practicing sport & 24 & 26 \\
\hline
\end{tabular}




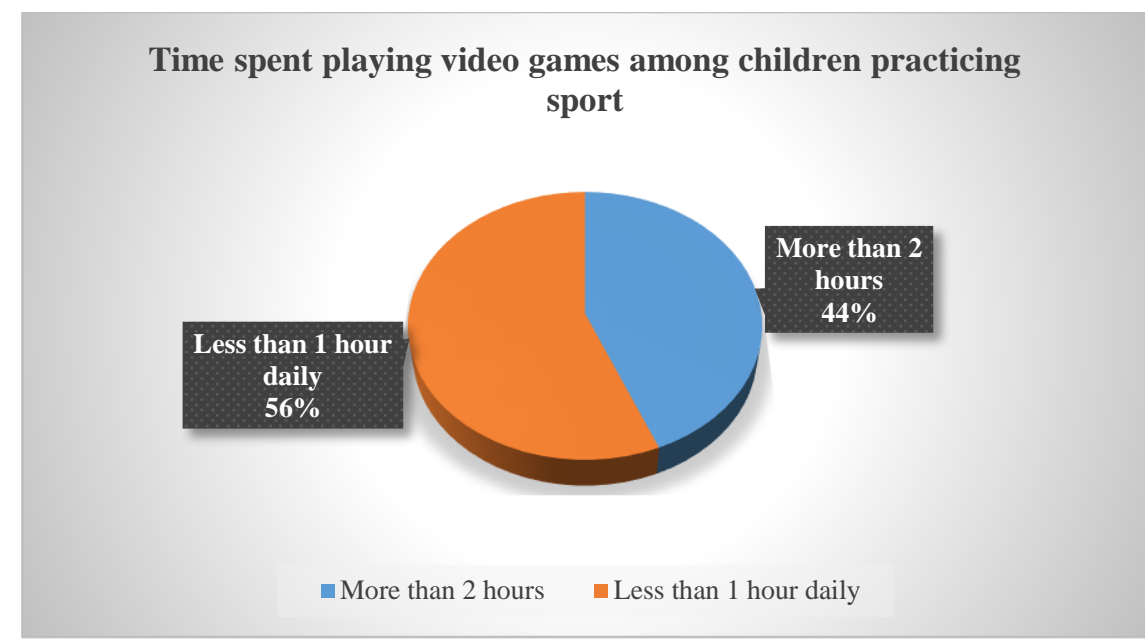

Figure 3. Time spent playing video games among children practicing sport

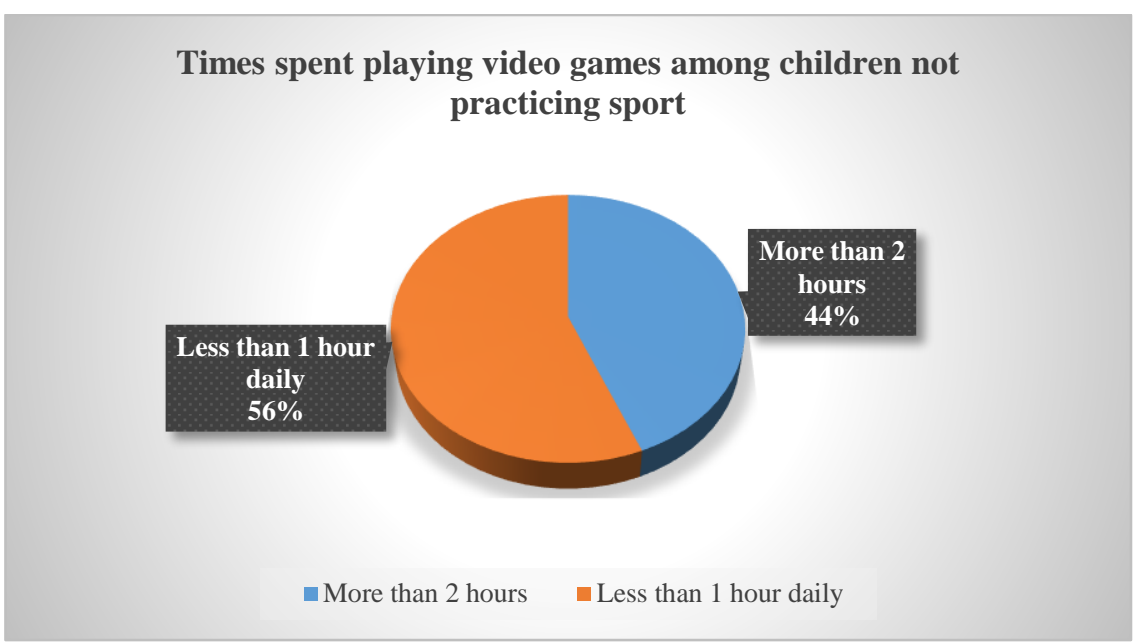

Figure 4. Time spent playing video games among children not practicing sport

The differences that occur between children who practice a leisure or performance sport and those who do not practice sport are presented below. Regarding the time spent playing video games and using gadgets in general, there is a higher percentage of children who do sport than use gadgets less than one hour per day - 64\% versus $48 \%$ (Table 2, Figure 2).

We analysed separately the results of boys and girls, dividing the two groups into children who spend less than one hour a day playing or socialising with the mentioned devices and children who do this more than two hours a day. The obtained results are shown in Table 3 for boys and Table 4 for girls.

Table 3. Statistical results from the assessment of motor skills - Boys

\begin{tabular}{|c|c|c|c|c|c|c|c|c|}
\hline & Boys & & $3 \times 10 \mathrm{~m}$ & $30 \mathrm{~m}$ & $\begin{array}{l}\text { Long } \\
\text { jump }\end{array}$ & $400 \mathrm{~m}$ & Flexibility & $\begin{array}{l}\text { On-line } \\
\text { response } \\
\text { time }(\mathrm{ms})\end{array}$ \\
\hline \multirow{8}{*}{$\begin{array}{l}\text { Time spent on } \\
\text { device - less } \\
\text { than } 1 \text { hour/ } \\
\text { day }\end{array}$} & \multirow{2}{*}{$\mathrm{N}$} & Valid & 24 & 24 & 24 & 24 & 24 & 21 \\
\hline & & Missing & 0 & 0 & 0 & 0 & 0 & 3 \\
\hline & Mean & & 9.09 & 5.78 & 1.45 & 1.48 & 1 & 558 \\
\hline & Median & & 9.17 & 5.85 & 1.42 & 1.5 & 1 & 475 \\
\hline & Std. Deviation & & 0.59 & 0.44 & 0.23 & 0.5 & 7.01 & 159 \\
\hline & Minimum & & 7.78 & 4.75 & 0.95 & 1.27 & -12 & 370 \\
\hline & Maximum & & 10.25 & 6.84 & 1.9 & 3.5 & 20 & 870 \\
\hline & & 10 & 8.09 & 5.17 & 1.2 & 1.36 & -9.5 & 390 \\
\hline
\end{tabular}


International Proceedings of Human Motricity/ ICPESK 2019

Supplementary Issue of Discobolul - Physical Education, Sport and Kinetotherapy Journal, 2019

\begin{tabular}{|c|c|c|c|c|c|c|c|c|}
\hline & \multirow{10}{*}{ Percentiles } & 20 & 8.5 & 5.32 & 1.26 & 1.38 & -5 & 410 \\
\hline & & 25 & 8.82 & 5.62 & 1.31 & 1.44 & -4 & 415 \\
\hline & & 30 & 8.88 & 5.68 & 1.32 & 1.46 & -3.5 & 420 \\
\hline & & 40 & 9.03 & 5.69 & 1.38 & 1.48 & -1 & 448 \\
\hline & & 50 & 9.17 & 5.84 & 1.42 & 1.5 & 1 & 470 \\
\hline & & 60 & 9.38 & 5.88 & 1.49 & 1.54 & 1 & 480 \\
\hline & & 70 & 9.45 & 5.94 & 1.56 & 1.56 & 3.5 & 548 \\
\hline & & 75 & 9.5 & 5.96 & 1.6 & 1.97 & 4.75 & 635 \\
\hline & & 80 & 9.56 & 6 & 1.66 & 2.12 & 5 & 716 \\
\hline & & 90 & 9.7 & 6.34 & 1.84 & 2.28 & 8.5 & 830 \\
\hline \multirow{18}{*}{$\begin{array}{l}\text { Time spent on } \\
\text { device - more } \\
\text { than } 2 \text { hours/ } \\
\text { day }\end{array}$} & \multirow{2}{*}{$\mathrm{N}$} & Valid & 31 & 30 & 31 & 30 & 30 & 29 \\
\hline & & Missing & 0 & 1 & 0 & 1 & 1 & 2 \\
\hline & Mean & & 9.35 & 5.87 & 1.4 & 2.08 & -2.8 & 542 \\
\hline & Median & & 9.22 & 5.8 & 1.42 & 2.01 & -0.5 & 495 \\
\hline & Std. Deviation & & 0.67 & 0.60 & 0.19 & 0.476 & 9.05 & 126 \\
\hline & Minimum & & 8.22 & 4.87 & 0.95 & 1.32 & -20 & 350 \\
\hline & Maximum & & 11.09 & 7.38 & 1.9 & 3 & 18 & 850 \\
\hline & \multirow{11}{*}{ Percentiles } & 10 & 8.41 & 5.12 & 1.2 & 1.4 & -14.9 & 410 \\
\hline & & 20 & 8.79 & 5.31 & 1.23 & 1.44 & -9.6 & 450 \\
\hline & & 25 & 8.84 & 5.46 & 1.28 & 1.48 & -8 & 450 \\
\hline & & 30 & 8.94 & 5.62 & 1.31 & 1.5 & -7.7 & 450 \\
\hline & & 40 & 9.16 & 5.68 & 1.36 & 1.56 & -6.2 & 470 \\
\hline & & 50 & 9.22 & 5.8 & 1.42 & 2 & -0.5 & 490 \\
\hline & & 60 & 9.37 & 5.86 & 1.46 & 2.19 & 2.2 & 510 \\
\hline & & 70 & 9.61 & 6.15 & 1.5 & 2.23 & 5.4 & 530 \\
\hline & & 75 & 9.84 & 6.31 & 1.54 & 2.24 & 6 & 540 \\
\hline & & 80 & 9.85 & 6.34 & 1.55 & 2.26 & 6 & 590 \\
\hline & & 90 & 10.39 & 6.82 & 1.59 & 2.41 & 7.9 & 820 \\
\hline
\end{tabular}

Table 4. Statistical results from the assessment of motor skills - Girls

\begin{tabular}{|c|c|c|c|c|c|c|c|c|}
\hline & Girls & & $3 \times 10 \mathrm{~m}$ & $30 \mathrm{~m}$ & $\begin{array}{l}\text { Long } \\
\text { jump }\end{array}$ & $400 \mathrm{~m}$ & Flexibility & $\begin{array}{l}\text { On-line } \\
\text { response } \\
\text { time }(\mathrm{ms})\end{array}$ \\
\hline \multirow{20}{*}{$\begin{array}{l}\text { Time spent on } \\
\text { device - less } \\
\text { than } 1 \text { hour/ } \\
\text { day }\end{array}$} & \multirow{2}{*}{$\mathrm{N}$} & Valid & 40 & 40 & 40 & 40 & 38 & 37 \\
\hline & & Missing & 0 & 0 & 0 & 0 & 2 & 3 \\
\hline & Mean & & 9.43 & 5.78 & 1.47 & 2.02 & 6 & 553 \\
\hline & Median & & 9.4 & 5.78 & 1.43 & 2.01 & 7 & 535 \\
\hline & Std. Deviation & & 0.5 & 0.43 & 0.16 & 0.36 & 6.26 & 117 \\
\hline & Minimum & & 8.37 & 4.94 & 1.2 & 1.3 & -16 & 370 \\
\hline & \multirow[t]{6}{*}{ Maximum } & & 11.09 & 6.88 & 1.81 & 2.44 & 20 & 890 \\
\hline & & 10 & 8.79 & 5.18 & 1.26 & 1.36 & 1 & 418 \\
\hline & & 20 & 9.07 & 5.45 & 1.34 & 1.48 & 2.8 & 440 \\
\hline & & 25 & 9.13 & 5.51 & 1.36 & 1.51 & 3.75 & 460 \\
\hline & & 30 & 9.15 & 5.55 & 1.39 & 1.53 & 4 & 464 \\
\hline & & 40 & 9.27 & 5.66 & 1.4 & 1.57 & 6 & 490 \\
\hline & \multirow[t]{6}{*}{ Percentiles } & 50 & 9.4 & 5.78 & 1.43 & 2.04 & 7 & 520 \\
\hline & & 60 & 9.55 & 5.85 & 1.47 & 2.06 & 8 & 548 \\
\hline & & 70 & 9.7 & 5.97 & 1.56 & 2.11 & 10 & 592 \\
\hline & & 75 & 9.76 & 6.03 & 1.6 & 2.15 & 11 & 610 \\
\hline & & 80 & 9.78 & 6.11 & 1.64 & 2.19 & 11 & 634 \\
\hline & & 90 & 9.95 & 6.27 & 1.72 & 2.24 & 14 & 740 \\
\hline & \multirow{2}{*}{$\mathrm{N}$} & Valid & 17 & 17 & 17 & 17 & 16 & 16 \\
\hline & & Missing & 0 & 0 & 0 & 0 & 1 & 1 \\
\hline \multirow{7}{*}{$\begin{array}{l}\text { Time spent on } \\
\text { device - more } \\
\text { than } 2 \text { hours/ } \\
\text { day }\end{array}$} & Mean & & 9.52 & 5.96 & 1.43 & 2.04 & 3.85 & 606 \\
\hline & Median & & 9.57 & 5.93 & 1.39 & 2.13 & 4 & 600 \\
\hline & Std. Deviation & & 0.56 & 0.6 & 0.17 & 0.30 & 8.86 & 207 \\
\hline & Minimum & & 8.5 & 4.94 & 1.22 & 1.4 & -15 & 350 \\
\hline & Maximum & & 10.41 & 7.1 & 1.73 & 2.48 & 18 & 950 \\
\hline & & 10 & 8.77 & 5.09 & 1.23 & 1.42 & -10.8 & 377 \\
\hline & & 20 & 8.92 & 5.27 & 1.27 & 1.84 & -4.4 & 408 \\
\hline
\end{tabular}


International Proceedings of Human Motricity/ ICPESK 2019

Supplementary Issue of Discobolul - Physical Education, Sport and Kinetotherapy Journal, 2019

\begin{tabular}{cccccccc}
\hline & 25 & 9.01 & 5.46 & 1.29 & 2.01 & 1.25 & 430 \\
& 30 & 9.09 & 5.69 & 1.3 & 2.01 & 2 & 461 \\
& 40 & 9.22 & 5.9 & 1.36 & 2.03 & 2.8 & 486 \\
Percentiles & 50 & 9.57 & 5.93 & 1.39 & 2.13 & 4 & 615 \\
& 60 & 9.75 & 6.12 & 1.4 & 2.15 & 5.2 & 694 \\
& 70 & 10.01 & 6.21 & 1.56 & 2.2 & 7.8 & 719 \\
& 75 & 10.11 & 6.25 & 1.61 & 2.21 & 9.5 & 847.5 \\
& 80 & 10.14 & 6.43 & 1.62 & 2.23 & 11.2 & 902 \\
& 90 & 10.35 & 6.9 & 1.71 & 2.42 & 17.3 & 922 \\
\hline
\end{tabular}

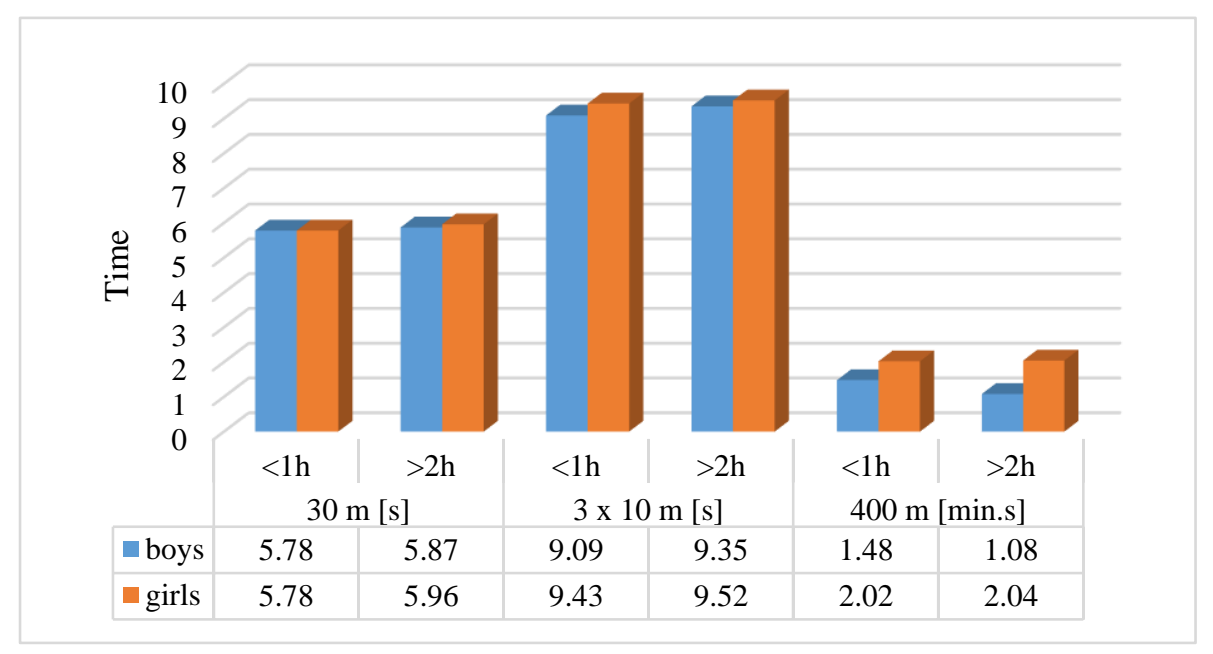

Figure 5. Average test results for boys and girls - Time

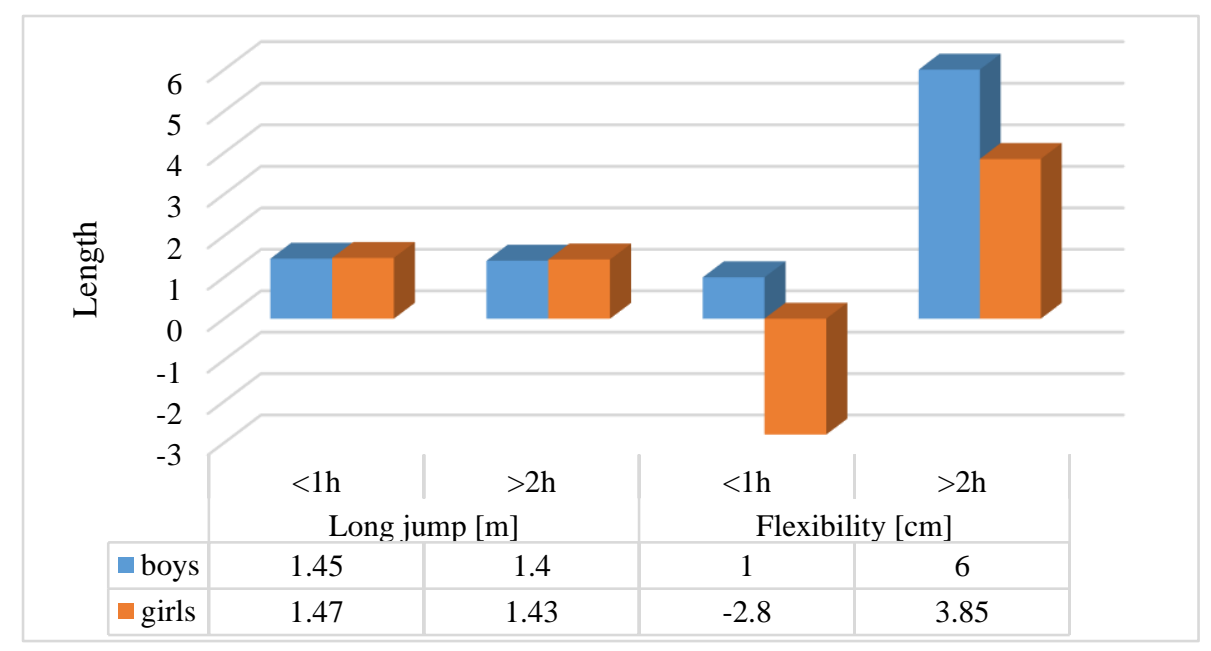

Figure 6. Average test results for boys and girls - Length

Table 5. Better results than average

\begin{tabular}{llccccc}
\hline & & avg $(1)$ & $<1$ hour & $<1$ hour & $>2$ hours & $>2$ hours \\
\cline { 3 - 7 } & & & $\mathrm{N}<$ avg & $\%<$ avg & $\mathrm{N}<$ avg & $\%<$ avg \\
\hline \multirow{2}{*}{$30 \mathrm{~m}$} & boys & 5.78 & $9 / 19$ & 47.37 & $12 / 26$ & 46.15 \\
& girls & 5.78 & $19 / 38$ & 50 & $6 / 17$ & 35 \\
\hline \multirow{2}{*}{ Lon jo m jump } & boys & 9.09 & $12 / 21$ & 57.14 & $10 / 19$ & 47.37 \\
& girls & 9.43 & $17 / 35$ & 48.57 & $8 / 17$ & 47.06 \\
\hline \multirow{2}{*}{$400 \mathrm{~m}$} & boys & 1.45 & $12 / 22$ & 54.55 & $12 / 25$ & 48 \\
& girls & 1.47 & $14 / 28$ & 50 & $6 / 14$ & 42 \\
\hline & boys & 1.48 & $7 / 17$ & 41.18 & $6 / 25$ & 24 \\
& girls & 2.01 & $17 / 33$ & 51.52 & $4 / 16$ & 25.00 \\
\hline
\end{tabular}


International Proceedings of Human Motricity/ ICPESK 2019

Supplementary Issue of Discobolul - Physical Education, Sport and Kinetotherapy Journal, 2019

\begin{tabular}{llccccc}
\hline Flexibility & boys & 1 & $8 / 16$ & 50.00 & $8 / 20$ & 40.00 \\
& girls & 6 & $10 / 17$ & 58.82 & $6 / 14$ & 42.86 \\
\hline Response time & boys & 542 & $10 / 16$ & 62.50 & $13 / 18$ & 72.22 \\
& girls & 553 & $15 / 27$ & 55.56 & $7 / 15$ & 46.67 \\
\hline
\end{tabular}

Table 5 shows that, in the motor tests, the average test results are weaker for both the group of boys and the group of girls who spend more than 2 hours per day using the mentioned gadgets. The only exception (somehow predictable) occurred in the case of the reaction time test for boys who spend more than 2 hours connected to their gadgets. This is explained by the "training" accumulated through the video games they play (very often, shooter or sport games requiring attention and quick reaction). In the case of girls, the situation is different, their average reaction time being much longer for the second group, especially due to the penalties received by many of them.

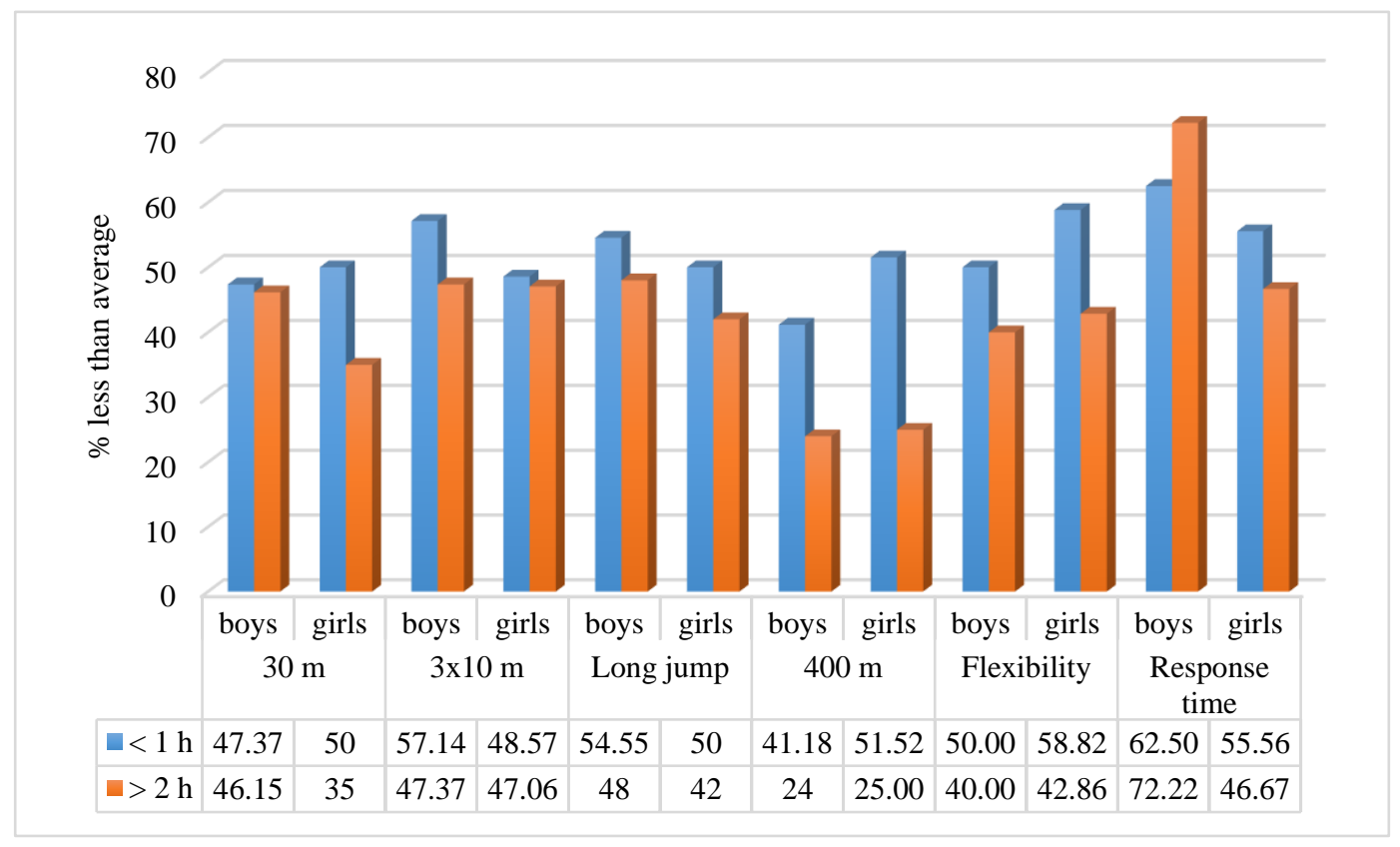

Figure 7. Relating performance to average values for the four groups of subjects

In the 30-m distance running test, the difference (expressed as a percentage) between boys playing less than 2 hours and boys playing for more than 2 hours is statistically insignificant, yet better results are in favour of those who play less in the virtual environment, the percentage of those who exceeded the average value (5.78 s) being higher. It cannot be said the same about girls, with $50 \%$ of girls in the first group having better times than average, while in the second group. only $35 \%$ have achieved this performance.

In the $3 \times 10 \mathrm{~m}$ test, the differences between the groups of girls are very small, while the boys are slightly more consistent (with 10\% fewer boys in the second group having achieved better performance than the 9.09 s average).

We can make the same observations for all other tests, with a higher percentage of children with better than average results belonging to the group that plays less than 1 hour daily on his gadget.

As expected, in the response time test, the boys in the second group recorded, in higher percentage, better response time than the average (because the games they play require focus and quick responses) compared to the group that uses less such devices.

The girls in the second group recorded lower reaction time than the average especially due to penalties and lack of attention. The girls in the first group, most of them also practicing sport in their free time, demonstrated a greater ability to concentrate and react quickly (the lowest reaction time for a girl in the first group belongs to a multiple national champion in swimming and biathlon).

\section{Conclusion}

The development of contemporary society generates an unprecedented quantitative and qualitative growth in all areas including in the sport field (Szabo, 2015). Gadgets like smartphone, tablet and laptop are magical objects for digital children. These objects are not bad. The lack of parental experience and concern is the problem. If these 
devices were to be used as learning tools (they offer so many possibilities) rather than a means for parents to gain some peace of mind or as a refuge for children in a world where they seem to have control and whose error is erased by one click, the danger would be much smaller. Given that sedentary lifestyle and obesity have become particularly menacing enemies of Europeans and Americans, including children, and the disorders caused by long contact with these devices have not been eliminated, a balance must be established between the children's movement programs and those dedicated to learning. The level reached today by the development of sports practice, like any activity with interdisciplinary features, shall be subject to a permanent dynamic alert, leaving at hand techniques and means with which to act in practice (Szabo, 2015).

The role of information technology in our lives must not be neglected; the electronic devices are very useful in nowadays sports performance as many scientific papers prove (Szabo et al., 2019a), therefore we must accept that the next generations are perhaps more versatile than we are, but, beyond all of this, it must be taken into account that an alert mind and good mental tone will characterise a healthy, active child with good motor control, well adapted to the environment and integrated into the social group to which they belong. These desires can be fulfilled by constantly practicing sport, not necessarily performance sport.

We have presented here the evidence that most children who spend more than two hours a day playing or watching devices have poorer results in the motor skill tests than those who spend only one hour or less doing this, especially because they allocate less time to physical exercise, movement and sports.

\section{References}

CSID. (2017). Tehnologia și influența sa negativă asupra dezvoltării copilului [Technology and its negative influence on child development]. Retrieved from https://www.csid.ro/family/crestere-copii/tehnologia-siinfluenta-sa-negativa-asupra-dezvoltarii-copilului-16501000

Institutul Național de Cercetare pentru Sport. (2016). Programul Biomotric [The Biomotor Programme]. Retrieved from http://www.biomotric.ro/masuratori_biomotrice/mobilitate

McCrindle, M. (2014). The ABC of XYZ. Understanding the global generations. Bella Vista, NSW: McCrindle Research Pty Ltd.

Montresor, F. (2016). The 7 technologies changing your world. Retrieved from https://www.weforum.org/agenda/2016/01/a-brief-guide-to-the-technologies-changing-world/

Neuroscience for kids. (2017). On-line response time experiments. Retrieved from https://faculty.washington.edu/chudler/chgames.html

Noel, A. (2018). Copiii deconectați de lumea reală sau cum ișsi cumpără părinții liniștea [Children disconnected from the real world or how parents buy their peace of mind]. Retrieved from http://www.antonianoel.com/copiii-deconectati-de-lumea-reala-sau-cum-isi-cumpara-parintii-linistea/

Sopa, I. S. (2014a). Study regarding group cohesion at primary level. Bulletin of the Transylvania University of Brasov, 56(1), 67-74. $\quad$ Retrieved from http://webbut.unitbv.ro/BU2014/Series\%20IX/BULETIN\%20IX\%20PDF/III-2_SOPA.pdf

Sopa, I. S. (2014b). The socializing role of motor activities at primary school level. Bulletin of the Transylvania University of Brasov, 56(2), 43-50. Retrieved from http://webbut.unitbv.ro/BU2014/Series\%20IX/BULETIN\%20IX/06_SOPA_bun.pdf

Szabo, D. A. (2016). Modalities of using the information provided by the statistical program Click and Scout for improving the outside hitters' service efficiency in volleyball game. The European Proceedings of Social \& Behavioral Sciences, XI, 341-347. http://dx.doi.org/10.15405/epsbs.2016.06.47

Szabo, D. A. (2015). Study on improving the service unforced errors in volleyball game by using a statistical software. In I. Roceanu (Ed.), Proceedings of the $11^{\text {th }}$ Interational Scientific Conference eLearning and Software for Education, April 23-24, 2015 (Vol. 3, pp. 320-326). DOI: 10.12753/2066-026X-15-229

Szabo, D. A., Neagu, N., Teodorescu, S., Pomohaci, M., \& Sopa, I. S. (2019a). Modalities of exploitation the information provided by Click \& Scout program in preparing volleyball attack players. International Journal of Applied Exercise Physiology, 8(2.1), 775-782. Retrieved from http://ijaep.com/Journal/vol.8.2.1.pdf

Szabo, D. A., Neagu, N., Teodorescu, S., Pomohaci, M. \& Sopa, I. S. (2019b). Does smart electronic devices influence the body deficiencies development at kids who practice swimming? International Journal of Applied Exercise Physiology, 8(2.1), 768-774. Retrieved from http://ijaep.com/Journal/vol.8.2.1.pdf

Technology. (n.d.). In Lexico. Retrieved from https://www.lexico.com/en/definition/technology 